\title{
(5)

\section{Glukosebelastningstesting av de fleste gravide er en dårlig idé}

DEBATT

\section{ANNE ESKILD}

E-post: anne.eskild@medisin.uio.no Anne Eskild er overlege på Kvinneklinikken ved Akershus universitetssykehus og professor II ved Institutt for klinisk medisin, Universitetet i Oslo.

Forfatter har fylt ut ICMJE-skjemaet og oppgir ingen interessekonflikter.

\section{ATLE KLOVNING}

Atle Klovning er fastlege ved Frogner helsesenter i Oslo og førsteamanuensis ved Institutt for helse og samfunn, Universitetet iOslo.

Forfatter har fylt ut ICMJE-skjemaet og oppgir ingen interessekonflikter.

\section{ELISABETH SWENSEN}

Elisabeth Swensen er spesialist i allmennmedisin, fast skribent Klassekampen og redaksjonell medarbeider i Tidsskriftet.

Forfatter har fylt ut ICMJE-skjemaet og oppgir ingen interessekonflikter.

\section{KJELL $\AA$. SALVESEN}

Kjell Å. Salvesen er klinikksjef for Kvinneklinikken ved St. Olavs hospital og professor II ved Institutt for klinisk og molekylærmedisin, Norges teknisk naturvitenskaplige universitet.

Forfatter har fylt ut ICMJE-skjemaet og oppgir ingen interessekonflikter.

De nye retningslinjene for glukosebelastningstesting av de fleste gravide bryter med sentrale forutsetninger for et screeningprogram.

Fra 2018 skal alle førstegangsgravide over 25 år, dvs. 80\% av førstegangsgravide, tilbys glukosebelastningstest i svangerskapsuke 24-28 (1) (se flytskjema). Gravide med pregravid kroppsmasseindeks over 25 og kvinner fra land med høy forekomst av diabetes, skal også tilbys glukosebelastningstest. Trolig oppfyller minst 40 ooo gravide kvinner disse kriteriene årlig.

Professor Bjørn Backe har tidligere omtalt de nye retningslinjene som «å skyte spurv med kanoner» (2). Flere fastleger har ment at friske gravide sykeliggjøres (3). Tore Henriksen og medarbeidere hevder derimot at screening med glukosebelastningstest er nødvendig for bedre identifikasjon av gravide med høyt blodsukker (4). Men det er flere faktorer enn sensitiv diagnostikk som har betydning i vurderingen om et screeningprogram skal innføres (5). 


\section{Krav til dokumentasjon}

Hvis man skal innføre et nytt screeningprogram, bør den forventede effekten av programmet som helhet være godt dokumentert (5).Vi har ikke klart å finne noen dokumentasjon for at primærscreening med glukosebelastningstest bidrar til færre komplikasjoner enn dagens retningslinjer, som blant annet omfatter screening av alle gravide for glukosuri.

Effekten av et screeningprogram avhenger av at intervensjonen som tilbys, forebygger komplikasjoner. For kvinner med mild svangerskapsdiabetes omfatter intervensjonen livsstilsråd som stort sett sammenfaller med de rådene som gis til alle gravide. Effekten av enkelte livsstilsråd diskuteres (2). Risikoen for å få et stort barn eller svangerskapsforgiftning er større for kvinner med diabetes før svangerskapet enn for kvinner som utvikler svangerskapsdiabetes $(6,7)$. Det er et paradoks at de kvinnene med pregravid diabetes og som svangerskapsomsorgen følger tettest med kostholdsråd og insulinbehandling, har høyest forekomst av komplikasjoner.

\section{Et betydelig helseproblem?}

I Norge får kvinner med svangerskapsdiabetes barn som i gjennomsnitt er $100 \mathrm{~g}$ tyngre enn kvinner uten diabetes (7), og barn med fødselsvekt rundt 80 \%-prosentilen ser ut til å ha best prognose (8). Gjennomsnittlig fødselsvekt har gått ned. Også forekomsten av analsfinkterrupturer, som er sterk knyttet til fødsel av et stort barn, er redusert. Perinatal dødelighet er fallende, til tross for økning i forekomsten av svangerskapsdiabetes og risikofaktorer for svangerskapsdiabetes, slik som høy kroppsmasseindeks, høy alder og opprinnelse fra land med høy forekomst av diabetes. Diabetes gir økt risiko for svangerskapsforgiftning, men norske gravide med svangerskapsforgiftning har knapt noen $\emptyset \mathrm{kt}$ risiko for fosterdød (9).

\section{Gevinsten større enn ulempene?}

Glukosebelastning kan oppleves som belastende og tidkrevende. Derfor vil kanskje noen ikke møte til svangerskapskontroller og dermed svekke gevinsten av screeningen og svangerskapsomsorgen som helhet. Mange helsearbeidere synes at glukosebelastning i det omfanget de de nye retningslinjene legger opp til, krever mye tid og ressurser (3). Helsepersonell har allerede mer enn nok å gjøre.

Prinsippet om ikke å gjøre mer skade enn gavn er særlig viktig ved tiltak hos gravide. Både mor og det ufødte barnet berøres. Kan faste før glukosebelastningstest være skadelig for noen mødre eller fostre? Påfører screeningen unødvendig engstelse for sykdom? Svekkes helsetjenestens mål om å unngå unødvendige og skadelige undersøkelser? En intervensjon som faktisk reduserer blodsukkerkonsentrasjonen og barnets fødselsvekt, vil sannsynligvis flytte fordelingen av fødselsvekter mot lavere verdier. Å ha lav fødselsvekt er sannsynligvis verre enn å ha høy. Kostnadene ved de nye screeningrutinene er betydelige. Så vidt vi vet, har det ikke vært utført noen kostnad-nytte-analyse.

\section{Forutsetningene for ny screening}

I iveren etter å identifisere gravide med høyt blodsukker, må helsemyndighetene ha glemt viktige forutsetninger for å innføre et screeningprogram: å dokumentere omfanget av helseproblemet knyttet til svangerskapsdiabetes samt å vekte og veie de positive og negative effektene av screeningen. Vi mener derfor at de nye retningslinjene for svangerskapsdiabetes ikke bør brukes før slik dokumentasjon blir lagt frem.

1. Svangerskapsdiabetes. Nasjonal faglig retningslinje for svangerskapsdiabetes. Helsedirektoratet. 
https://helsedirektoratet.no/retningslinjer/svangerskapsdiabetes (19.12.2018).

2. Backe B. Å skyte spurv med kanoner. Tidsskr Nor Legeforen 2018; 138. doi:10.4045/tidsskr.18.0167.

[PubMed][CrossRef]

3. Mjølstad BP, Roksund G, Brelin P et al. Fare for medikalisering av gravide tas ikke på alvor! Tidsskrift Nor Legeforen 2018.

https://tidsskriftet.no/2018/o6/kommentar/fare-medikalisering-av-gravide-tas-ikke-pa-alvor (21.12.2018).

4. Henriksen T, Jenum AK, Thordarson HB et al. Lite nytt i kritikk av retningslinjene for svangerskapsdiabetes. Tidsskr Nor Legeforen 2018;138. doi: 10.4045/tidsskr.18.0430.

[PubMed][CrossRef]

5. Wilson JMG, Junger G. Principles and practice of screening for disease. Public Health Papers 34. Geneve: World Health Organization, 1968.

http://apps.who.int/iris/bitstream/handle/10665/37650/WHO_PHP_34.pdf?sequence=17 (21.12.2018).

6. Dypvik J, Strøm-Roum EM, Haavaldsen C et al. Preeclampsia in pregnancies with and without diabetes: the associations with placental weight. A population study of 655842 pregnancies. Acta Obstet Gynecol Scand 2016; 95: 217-24. [PubMed][CrossRef]

7. Strøm-Roum EM, Tanbo TG, Eskild A. The associations of maternal body mass index with birthweight and placental weight. Does maternal diabetes matter? A population study of 106191 pregnancies. Acta Obstet Gynecol Scand 2016; 95: 1162-7o. [PubMed][CrossRef]

8. Vasak B, Koenen SV, Koster MP et al. Human fetal growth is constrained below optimal for perinatal survival. Ultrasound Obstet Gynecol 2015; 45: 162-7. [PubMed][CrossRef]

9. Basso O, Rasmussen S, Weinberg CR et al. Trends in fetal and infant survival following preeclampsia. JAMA 2006; 296: 1357-62. [PubMed][CrossRef]

Publisert: 17. januar 2019. Tidsskr Nor Legeforen. DOI: 10.4045/tidsskr.18.0898

Mottatt 19.11.2018, første revisjon innsendt 11.12.2018, godkjent 21.12.2018.

(C) Tidsskrift for Den norske legeforening 2020. Lastet ned fra tidsskriftet.no 